\title{
UNA LECTURA CARNAVALESCA DEL RELATO DEL TOHUEYO Y DEL CICLO DE RENOVACIÓN DE QUETZALCOATL, DESTRONADO POR LOS DIOSES DESESTABILIZADORES UITZILOPUCHTLI Y TITLACAOAN
}

\section{Miguel Ángel Malpartida*}

\section{CARNAVAl Y CARNAVALIZACIÓN}

La imagen del grotesco se caracteriza por un constante movimiento hacia lo bajo material y corporal, inacabado y abierto al mundo, en desmedro de la imagen perfectamente cerrada y acabada de la proporción. El grotesco privilegia el desborde y la tensión corporal, los estados del cuerpo crítico y cambiante como el nacimiento, la agonía-muerte y el coito, instantes en que el cuerpo grotesco adquiere la categoría de cuerpo social y cuerpo cósmico, se enlaza al cuerpo del otro, da o entrega la energía poseída en un perfecto estado de dramatización del propio cuerpo.

Lógicamente, la expresión de estas tensiones cargadas de crudeza, se encuentran proscritas de la visión oficial del mundo occidental. Bajtín rastrea, en su libro La cultura Popular en la Edad Media y el Renacimiento, las manifestaciones de lo que él denomina carnavalización en la obra de François Rabelais. La carnavalización resultaría ser la incursión de las imágenes de la cultura popular en su momento de carnaval y todo el sistema simbólico que

* Es docente de Seminario de Literatura de la Facultad de Ciencias de la Educación de la UCSS. 
encierra este fenómeno social, en la constitución de la cultura oficial, no tanto como una particularidad extraña, sino más bien como un elemento que, en el rebajamiento de las imágenes oficiales, cede el paso a una verdadera renovación de sentido. Las imágenes grotescas de las fiestas populares de la Edad Media, sus rituales, sus manifestaciones artísticas, discursivas y gestuales dirigidas a la exaltación del cuerpo como elemento material más importante, verdadero, social e histórico, nos brindan una visión del mundo completamente opuesta al estático modelo medieval imperante, pletórico de normativa dogmática, abstracta, inamovible, falsamente inclinada a la eternidad de sus preceptos literarios, lingüísticos, religiosos y políticos. El mundo vertical opresor es liberado durante la fiesta utópica del carnaval, que de por sí privilegia la igualdad y por tanto la horizontalidad, pero proveniente de una necesaria inversión y un tiempo efímero. Durante la época del Carnaval, que podía durar días e incluso meses, el pueblo se lanzaba a las calles, a vivir ellos mismos, como personajes sociales, el mundo al revés, que significaba la supresión del orden jerárquico social, marcada por la desigualdad; la desacralización y burla de los elementos de la cultura oficial, consagrada siempre al orden de lo perenne e inmutable: los elementos religiosos eran parodiados en certámenes literarios, los formalismos y etiquetas eran reemplazados por la obscenidad y la risa burlona, las normas de castidad y pureza eran traicionadas de palmo a palmo por la predominancia del coito libre y la exaltación de lo genital. Era el cuerpo, en lugar del alma, el que vivía esta utópica fiesta, en donde lo bajo destronaba a lo alto: el exceso al ascetismo, lo profano a lo sagrado, la degradación a la solemnidad. A la coronación seguía el destronamiento. El humor y la risa popular soltaban la carcajada sobre el cadáver de lo estático y perfecto; lo grotesco paseaba arrogante sus exageradas protuberancias burlándose de todo lo perfecto y proporcionado. Bajtín nos indica que los mecanismos del carnaval se rigen primeramente por el contacto libre y familiar entre la gente; es decir, que todas las distancias sociales y jerárquicas entre las personas se aniquilan para comenzar un diálogo carnavalesco, en la plaza pública. La gente que vivía el carnaval entraba en el contacto familiar al compartir el mismo discurso carnavalesco, la parodia, la obscenidad, la vulgaridad. 
Esta primera categoría nos lleva a la segunda, que bien podría ser su efecto, y es que al presentarse la destrucción de las barreras sociales, procede un nuevo modo, invertido, de relaciones entre la gente. Todas las expresiones formales del hombre han sido eliminadas, y son relegadas a la marginalidad, y lo marginal, en las expresiones más naturales y concretas, sin amaneramientos, es mostrado y sirve de enlace con los demás vivenciadores del carnaval.

Ahora bien, el sujeto del carnaval adopta una actitud distinta y se vincula en distinto orden a lo que le deparó la vida social, y en sus estructuras mentales el orden también es invertido. Y es así como puede vincular ya, en un procedimiento de congregación de disparidades carnavalescas, lo que antes en la vida común, y no en este nuevo mundo, había estado separado y cerrado en su orden establecido: «Así el carnaval une, acerca, compromete, y conjuga lo sagrado con lo profano, lo alto con lo bajo, lo grande con lo miserable, lo sabio con lo estúpido» (Bajtín 1993: 174).

La cuarta categoría del carnaval estaría dirigida por la profanación, el rebajamiento y la mengua carnavalesca, para la cual se empleaban mecanismos como la sátira, la parodia, la burla, que ayudaban a desmitificar el discurso cultural oficial y aniquilarlo, para levantar sobre este un nuevo orden.

El fenómeno carnavalesco, a decir de Mijail Bajtín, no se establece mediante las palabras, imágenes o representaciones oficiales y canónicas, las cuales eluden ciertos aspectos del cuerpo como fuente de significación; sino por la revaloración y fecundización de las imágenes del cuerpo abierto (en contacto directo con el mundo), imágenes protuberantes, fluidas, grotescas y dotadas de las mayores certezas humanas, que demarcan el sentido de renovación y renacimiento dialéctico desde su permanente asociación con los hechos más concretos de la existencia. Estas vivencias del cuerpo, tales como el nacimiento, el coito y la agonía-muerte, son compartidas universalmente por todos los seres, sin distinciones sociales o políticas. Durante el carnaval, como hecho social compartido por todas las culturas, y por medio de la carnavalización, la influencia del evento social que se extiende a las formas artísticas concebidas por el hombre, estos hechos concretos, proscritos de la cultura oficial y asociados con la cultura popular, emergen y conforman 
un período en el cual las barreras sociales se disipan y surge un nuevo orden social entre las personas, en el cual sus formas de vida, creencias y conocimientos oficiales son rebajados y destinados a la marginalidad por una fuerza subversiva originada en el ámbito popular. El ordenamiento discursivo del carnaval puede adquirir y utilizar las expresiones mismas del poder oficial, con lo cual se renueva el sentido estático del canon, o también puede agenciarse de formas expresivas consideradas marginales por la literatura oficial.

\section{Mito y CARNAVALIZACIÓN}

Según Mircea Eliade, el mito relata una historia sagrada que ha tenido lugar en el tiempo primordial, y cuenta cómo, gracias a héroes sobrenaturales, una realidad sagrada ha cobrado forma en la existencia. El mundo de lo sagrado o lo sobrenatural, en el discurso del mito, irrumpe en el mundo conocido y justifica la existencia del hombre, corrobora su origen, sus ritos y actividades más significativas; y, agregamos, especialmente aquellas en las que el cuerpo se encuentra en plena transformación.

Aunque la carnavalización de la que trata Bajtín ejerce su análisis e interpretación sobre las formas populares de la Edad Media y el Renacimiento, no deja de ser sugerente que considere algunos aspectos universales de la carnavalización, que rastrea incluso desde la literatura de la Antigüedad griega (en las sátiras menipeas) y en los ritos saturnales romanos. No es casual que el desarrollo del fenómeno carnavalesco, a decir de Bajtín, tenga orígenes visibles en las sociedades del antiguo Occidente, en las cuales el pensamiento mítico era vigente y el mundo sobrenatural resultaba aún un sustento válido para los hechos de la realidad y viceversa. Estos aspectos son la risa y la renovación del mundo. El primero es un principio natural, biológico, que distingue al hombre del resto de seres vivos. Esta forma expresiva hace posible la libertad del humor como atenuante de los límites entre lo canónico y lo marginal. El segundo es un elemento presente en la estructura mítica de todas las sociedades, tanto antiguas como modernas: la vinculación entre los ciclos vitales de los seres individuales y los de la realidad toda (incluido el 
mundo sagrado); la certeza de que los Mundos o realidades cumplen un ciclo temporal determinado y buscan su renacimiento y regeneración.

Estos aspectos universales del carnaval, indestructibles, como los calificaría Bajtín, nos hablan del todo o del cosmos como una fuerza productiva perpetuamente inacabada que se manifiesta en la existencia misma de los seres a los que da vida. Los mitos primordiales tampoco están exentos de manifestar el carácter humorístico y festivo de las expresiones carnavalescas, debido a que ambos, mito y carnaval, poseen valor de concepción del mundo, es decir, se ocupan de reactualizar y simbolizar el vínculo entre el hombre y el cosmos que lo acoge.

A nuestro entender, la comparación entre la carnavalización y los mitos de renovación del mundo concuerda en señalar la revaloración de la simbología del cuerpo grotesco como cuerpo cósmico. El cuerpo grotesco, abierto al mundo en sus excrecencias, enlaza, mejor que el cuerpo proporcionado, con el mundo y los demás seres, ya que es un cuerpo cuyas funciones básicas (la alimentación y el coito) conservan el sentido renovador que lo asemeja a la naturaleza viva e inmortal. Entonces, el cuerpo deja de significar individualidad; se transforma en un cuerpo colectivo, compartido en común con las funciones biológicas de todos los seres del mundo pasado, presente y futuro: de la vida histórica. Las funciones más cercanas a lo concreto y material del cuerpo grotesco resultan ser las verdaderas fuerzas que vinculan al hombre con su entorno, y permiten que el cuerpo sea percibido ya no como una envoltura terminada y pudorosa, sino como un elemento de enlace con el mundo.

Esta apertura es examinada por Mircea Eliade, quien interpreta la escatología de los mitos de las sociedades arcaicas y avanzadas como la santificación de los elementos ligados a las funciones corporales. Con esto, Eliade refuerza su concepción de lo sagrado como la significación espiritual de las actividades humanas, y se aleja de la concepción estática de sacralidad como ocultamiento del cuerpo. En los mitos escatológicos de las sociedades primitivas y de las grandes culturas (entre ellas, las de América Central), los órganos del cuerpo y su fisiología reciben valoración religiosa debido a que se homologan con los fenómenos cósmicos y los actos divinos; se ritualizan y se convierten en modelos de las actividades humanas ligadas a la alimentación 
y la sexualidad: desde su aspecto más concreto y material, el cuerpo grotesco se convierte en sagrado cuerpo cósmico.

Ambas posiciones frente a la visión del cuerpo grotesco y su valoración religiosa, respectivamente, nos permiten elaborar una visión más sincrética: el pensamiento mítico de las antiguas sociedades y de las culturas avanzadas coinciden con la concepción carnavalesca del mundo en cuanto a la presencia del sentido festivo y regenerativo de sus imágenes corporales. Dichas imágenes hacen factible el pensar que las categorías principales de la carnavalización, universales en los sentidos antes mencionados, puedan presentarse en el pensamiento mítico de las culturas amerindias, en los relatos recogido por fray Bernardino de Sahagún en Historia general de las cosas de la Nueva España.

Asimismo, antes de empezar, conviene señalar que la lectura que se realizará de la Historia del Tohueyo, incluida en el Libro III, supone dos niveles de análisis: 1. el nivel pragmático, es decir, el enfrentamiento que evidencia la transcripción, recopilación y reordenamiento de los mitos y rituales recogidos por Sahagún de sus informantes; 2. El nivel simbólico de los relatos míticos, que involucran diversos héroes, ambientes y hechos sobrenaturales.

\section{LA MACROHISTORIA: EL DESPLAZAMIENTO DE LOS DIOSES}

A partir de la era moderna, los mitos como explicaciones válidas del mundo eran considerados intrascendentes, si no se apoyaban en la tradición filosófica o religiosa oficial. De este modo, se entiende la actitud de los religiosos, quienes no consideran que sus rituales y creencias también corresponden ciertamente a visiones o explicaciones míticas, y calificaban, en el mejor de los casos, de niñerías a las creencias religiosas amerindias, y en algunos otros, de amenazas idolátricas en contra de la implantación de la fe cristiana.

Por tanto, entendemos que, desde su situación pragmática, la Historia general de las cosas de la Nueva España de Bernardino de Sahagún caracteriza dos espacios enfrentados que se acrisolan en el mensaje: el del autor implícito y el narrador. El primero surge de la lectura, el otro es un elemento del propio texto. La percepción de la imagen del primero sugiere que su discurso sea refrendado por sus receptores letrados, las autoridades 
oficiales de la sociedad colonial; y que su contraparte en el texto, el narrador, cumpla, a diferencia del resto de cronistas e historiadores tendenciosos, con ofrecer una perspectiva objetiva y metódica de las creencias y formas de vida de los antiguos y contemporáneos mexicanos del s.XVI, que luego se ha identificado con la intención etnográfica de sus cuestionarios o minutas. Sobre la actitud del autor implícito de la Historia general, Todorov ha explicado que debe entenderse su ambivalencia (entre la admiración por el gobierno y la reprobación de lo sobrenatural) como el riesgo que significa apegarse a la neutralidad en el discurso. Afirma que, si bien el narrador de Sahagún no extiende ningún juicio de valor sobre los relatos, no deja de parangonar, para hacer comprensible a su lector inmediato el mundo que describe, el pasado de los antiguos mexicanos con el pasado de la cultura occidental. Así, los símiles entre los antiguos mitos griegos y romanos, y las historias del nacimiento, enfrentamientos, devociones y ritualidades de Quetzalcoatl, Uitzilopochtli y Titlacaoan, nos hacen pensar que el modo de inclusión de Sahagún mantiene su intención neutral, pero también ejecuta un reordenamiento desde la enciclopedia occidental.

Puede pensarse que esta forma de familiarizar al lector con los mitos toltecas a través de las referencias míticas del panteón clásico corresponde a una forma velada de revalorar la vigencia y validez del pensamiento mítico del vencido. Estaríamos frente a la irrupción de un discurso marginal o anticanónico, el mito, que emerge en un tipo de escritura formal que pretende recopilarlo. Creemos que la intención objetiva y la rigurosidad de Sahagún permiten que se filtren una serie de formas discursivas e imágenes corporales que colocan la labor y estilo del cronista en una circunstancia ambivalente frente al autor implícito que sus lectores deben construir.

La narración debiera empezar, si consideráramos la concepción lineal del tiempo, con el relato detallado del inicio de la macrohistoria en un espacio significativo para la religiosidad mesoamericana: Tula, el lugar de los juncos. Gordon Brotherston nos habla de un eminente desarrollo técnico y artístico de los toltecas, o nacidos en Tollan o Tula, en actividades tan diversas como la escribanía, arquitectura, pedrería, minería, orfebrería, música, medicina y astronomía. Las características del buen gobierno y sapiencia toltecas, aparte de la abundancia de sus tierras, hicieron que su 
población fuera considerada como el modelo de civilización mesoamericana. Estos avanzados conocimientos fueron instituidos, desde la visión mítica, por Quetzalcoatl, quien enseñó a los hombres todas las actividades, de modo especial el arte de tallar las piedras verdes, y la religiosidad: la penitencia de punzarse las piernas.

El espacio de este Tulla se describe como un lugar de la abundancia, en el cual la hiperbolización como recurso retórico destaca la inmensa fecundidad de sus tierras, cuyos productos —el maíz, las calabazas y los bledos - son sobredimensionados, tanto que los hombres empequeñecen frente a ellos.

La sociedad de Tulla bajo la advocación de Quetzalcoatl, a quien habían erigido el $c u$ más alto y de acceso más difícil por las muy angostas gradas, no conocía la carencia ni el hambre ni la destrucción.

Sin embargo, la narración empieza desde un ordenamiento distinto. Se narra, en primer lugar, el origen de los que llamaremos dioses desestabilizadores: Uitzilopuchtli y Titlacaoan.

El origen del primero se produce por fecundación de una pelotilla de plumas en el vientre de una mujer que cumplía penitencia en las cercanía de Tula, en la sierra de Coactépec. El acto de penitencia implica la estabilidad del ritual de retribución a la deidad por los favores recibidos o por recibir. Asumimos que esa divinidad era Quetzalcoatl, por la cercanía al centro religioso de Tula. Entonces, el momento de la fecundación de Uitzilopuchtli irrumpe en la religiosidad debida a Quetzalcoatl y además desarticula el orden social de un núcleo familiar. Coatlicue, debido a la fecundación, se ve enfrentada a su clan familiar: sus hijos, llamados centzonuitznáoa, quienes se avergüenzan por la concepción y, liderados por la hermana Coyolxauhqui, pretenden eliminar a su madre. Pero la inestabilidad creada por el dios concebido de este modo sobrenatural, esta vejación aparente del modelo materno y de la religiosidad, tiene una intención renovadora: el nacimiento de un nuevo orden, que surge intempestivamente de un modo violento y escatológico.

El niño sobrenatural, gracias a la ayuda de uno de los hermanos, quien será perdonado, sigue con atención el recorrido de los asesinos desde el vientre de su madre, a quien consuela con sus palabras. Cuando ya han 
llegado a matar a la madre, llega al mundo armado y vestido como guerrero, con el rostro pintado, y las extremidades y cabeza emplumadas (como la semilla de su concepción). De inmediato, hace pedazos a la hermana, y se echa a perseguir a los demás, que huyen por toda la tierra, pero que al fin son exterminados. Este dios renovador, que conjuga en el evento de su encarnación los elementos aparentemente dispares del ciclo vital, el nacimiento y la agonía-muerte, hace trizas a la primera humanidad (los hermanos asesinos) y se instituye como el dios de la guerra.

El desmembramiento al cual somete a su hermana parece ser también una constante en la ritualidad debida a Uitzilopuchtli. Para intentar una interpretación, debemos recordar que, en el tiempo utópico del carnaval, el cuerpo desmembrado es el cuerpo abierto por excelencia, y las mutilaciones que sufre son, en realidad, siembras corporales simbólicas de la división del mundo. En los ritos que involucran, como en el caso de Uitzilopuchtli, la celebración del año nuevo a través del sacrificio y del consumo del cuerpo de Dios, debe tenerse en cuenta el sentimiento de renovación del mundo que este conlleva. Los sacerdotes celebraban y representaban la muerte de Uitzilopuchtli; sin embargo, en realidad, su actividad tenía el sentido de renovación, en el cual la muerte es en realidad el inicio, la fecundación de la vida. Mircea Eliade sostiene que la celebración del año nuevo significa la renovación simbólica del mundo, el fin de un ciclo y, simultáneamente, el principio de otro. Los que participaban del culto anual, llamado Teucuaque, sabían que la penitencia costeada con leña para teas, maíz y mantas era mínima si se consideraba el riesgo que corría el mundo de perecer, si la ceremonia no fuese realizada. La ritualidad del carnaval, asimismo, agrega un detalle importante: sobrevive en las formas paganas de las religiones canónicas como el cristianismo, lo cual cuestionaría en gran medida las intenciones del compilador: tanto en el Cristianismo como en el culto a Uitzilopuchtli, al consumirse, durante el ritual, el cuerpo de la divinidad, la naturaleza divina se hace humana, porque los pedazos del cuerpo divino son sembrados en los cuerpos de los celebrantes, los cuales participan del momento sagrado y reciben el perdón, los beneficios de la deidad o la libertad de realizar sus vidas cotidianas. 
Por otra parte, el culto al otro dios desestabilizador, Titlacaoan, creador y proveedor de todo lo existente, poderoso e invisible, no carece de elementos carnavalescos. El dios dador y proveedor, era también un dios represor que castigaba el quebrantamiento de las penitencias de ayuno y abstinencia sexual con cruentas y visibles enfermedades contagiosas como la lepra o las bubas. Pero, ante esta aparente arbitrariedad del dios todopoderoso y amenazante, se erguía el reclamo del enfermo, que podía aplacar su mal, ora suplicando y prometiendo conversión, lo cual no se aleja de la sumisión debida a un ser tan misterioso; ora injuriando a la divinidad, es decir, destronándola por medio del insulto y la obscenidad: «Y el enfermo desesperado que no podía sanar, reñía enojado y dezía: “¡Oh, Titlacaoan, puto, hazéis burla de mí! ¿Por qué no me matais?” Y algunos enfermos sanavan y otros morían.» (Sahagún 2001: 280). Este destronamiento propugnaba, en el momento crítico de la agonía-muerte del devoto, en el momento de la transformación del cuerpo, la horizontalidad del contacto con la divinidad. En el momento del carnaval, la injuria y el elogio cobran su natural ambivalencia y se influyen mutuamente, tanto que persiguen una misma finalidad.

Recién en el tercer capítulo toma forma la referencia a Quetzalcoatl e inmediatamente después el relato de su decadencia. Gordon Brotherston explica que la visión renegada de los plebeyos que mantenían el lujo de Tula se manifiesta en diversos textos populares. Los abusos de la clase sacerdotal y política de esta región luminosa pronto la convierten en un lugar desestimado, ruinoso, cuyas gentes se dispersan.

Los dioses desestabilizadores ejercen otra vez la subversión, creemos, desde un punto de vista carnavalesco, que consiste en la renovación en los sucesos, por medio de la inventiva sobre la fuerza opresora, que es destronada. Ahora, Quetzalcoatl no es más un dios de la abundancia; está enfermo y envejecido: no puede desplazarse ni alcanzar con su poder a toda la región. Entonces, Titlacaoan, astutamente, se disfraza de un viejo y le lleva una medicina que promete devolverle la energía si se marcha lejos de Tula. Quetzalcoatl se resiste, pero finalmente, Titlacaoan logra que se emborrache, que se le «ablande el corazón» y quiera irse. 
La embriaguez es un elemento principal del banquete carnavalesco. En la vivencia del banquete, de la fruición y el agasajo del cuerpo, la bebida permite que los sujetos del carnaval accedan a la verdad festiva o verdad corporal. Quetzalcoatl desde su decadencia es tentado por el aparentemente envejecido Titlacaoan. En realidad, este último representa a la renovación que se produce a partir del propio acabamiento. Al dialogar los dos dioses, también dialogan la ritualidad oficial y la nueva ritualidad surgida en los márgenes, descontenta, insatisfecha con la decadente sociedad que ejerce el poder absoluto. La nueva divinidad convida el licor a la otra, que simboliza el vetusto orden; porque quiere hacer parir la verdad del propio cuerpo caduco de Quetzalcoatl. El licor permite a los vivenciadores del carnaval acceder al yo más íntimo, sin que medien las convenciones sociales que norman la conducta. Este lado irracional y probablemente inconsciente aflora en Quetzalcoatl, quien llora y se lamenta. Su tristeza no es renovadora, es una locura sombría, en la cual el espíritu del cambio ya no puede realizarse. Por medio de este diálogo taimado se completa el destronamiento y empieza la persecución, muy semejante a la que emprendió Uitzilopuchtli contra sus hermanos después de nacer.

\section{LA MICROHISTORIA: EL RELATO DEL TOHUEYO}

Los capítulos V, VI y VII nos ofrecen otro tipo de conversión de Titlacaoan. Ahora se transforma en un tohueyo o vendedor ambulante. En esta microhistoria, incluida en el nivel macro del enfrentamiento de dos facciones divinas, se presentan nuevamente los mecanismos característicos de la carnavalización, que, además, permiten el conflicto ambivalente del narrador en su relación con el autor implícito o modelo.

«Y el Uémac, que era señor de los tultecas en lo temporal, porque el dicho Quetzalcóatl era como sacerdote y no tenía hijos, tenía una hija muy hermosa [...]», afirma el narrador, casi al inicio del relato, para contextualizar la aparición del héroe tohueyo. La apreciación surge inmediatamente, si nos preguntamos por la división que establece el narrador (identificado con el autor implícito de sus receptores clérigos) entre el gobierno de lo temporal y el gobierno religioso o espiritual. Esta palabra, «temporal», nos permite 
reconocer la representación que hace de sí mismo el narrador. Al mencionar «en lo temporal», el narrador hace uso de la terminología teológica para nombrar el gobierno terrenal, transitorio o efímero, en oposición al orden de lo eterno, divino o intemporal. Si bien Quetzalcóatl es un dios comparado con los dioses paganos occidentales, por tanto erróneo; para sus devotos, parece señalar el narrador, era intemporal o divino. Sahagún, por razones de creencia e ideología, niega para Quetzalcóatl, tanto como para los héroes mitológicos del panteón occidental, la condición de dioses. Hacerlo hubiese significado una condena directa de sus receptores y hubiese complicado sus investigaciones posteriores; ${ }^{1}$ por lo tanto, les otorga la denominación de nigrománticos o hechiceros. Pero, para desestabilizar esta posición de poder frente a las creencias del otro, surgen las figuras retóricas: la hiperbolización, el símil y la sinécdoque.

En el capítulo cuarto, anterior al período que hemos destacado, el narrador ha deparado para Quetzalcóatl la denominación de gran nigromántico. Acaso sea una distinción implícita el otorgar tal título al dios dador y civilizador de los tultecas, similar en atributos al dios cristiano. La hiperbolización es un recurso poético que puede rastrearse tanto en la cultura popular medieval europea, como en las historias amerindias de Sahagún. Los frutos abundantes que recibían de Quetzalcoatl los tullanos están representados por la hiperbolización del tamaño. El dios Quetzalcoatl tenía el $c u$ más alto, la huerta mejor abastecida, las riquezas más codiciadas, y «las mazorcas de maíz eran tan largas que se llevaban abrazadas, y las cañas de bledos eran muy largos y gordos y que subían por ellas como por árboles». La

1 Como ciertamente lo fue, aunque por la falta de recursos económicos, como resultado del apego institucional a la pobreza eclesiástica. Es preciso aclarar que la investigación de Sahagún era un trabajo colectivo e implicaba recopilar testimonios, transcribirlos y traducirlos, ilustrarlos con gráficos y pictogramas, corregir, resumir y copiar de continuo los originales. Entre los años 1570 y 1575, la Provincia franciscana deja de prestarle el apoyo necesario y sus textos se dispersan. A pesar de ello, el autor intenta llamar la atención sobre su obra; por ello, envía al papado un resumen de varios libros de su Historia General; de este modo recibe una nueva autorización para continuar su trabajo. 
grandeza a que hace referencia no refuerza su contenido peyorativo, sino que es una injuria elogiosa, característica del rebajamiento carnavalesco. Mientras que, para el contexto oficial eclesiástico, la hiperbolización es negativa y el gran nigromántico debe ser condenado, para el mundo marginal de las narraciones míticas, releídas por Sahagún, Quetzalcoatl es representado como un gigante benéfico e ingenioso, un Hércules. El narrador cumple con poner a buen cubierto al autor implícito, pero tras sus expresiones aparentemente denigrantes, encontramos la revaloración de lo marginal: el dios pagano se equipara al dios indiano.

Si seguimos el rastro de las figuras hacia el símil, encontraremos que hay otra característica de la ambivalencia carnavalesca en el reconocimiento de Quetzalcoatl. El narrador no encuentra mejor modo de diferenciarlo de Uémac que definirlo como un sacerdote sin hijos. De este modo, asocia la actividad religiosa de la cultura amerindia al celibato, tal y como se estilaba en las comunidades eclesiásticas de su época, muy cercana al estilo de vida virtuosa de su imagen como autor implícto y también a la de sus receptores intencionales. Entendemos, entonces, que el mundo representado de la historia del tohueyo, narrada objetivamente por Sahagún, no está libre de expresar las formas de pensamiento del que les otorga la forma de libro escrito. La materia que se traduce poco a poco va tomando voz y lugar en la forma de narración, del mismo modo en que el grotesco emerge de lo proporcionado o modélico.

Si Quetzalcoatl es un sacerdote célibe, que complementa su poder con un orden temporal representado por Uémac, el gobernante; el tohueyo configura la amenaza natural y popular, que termina por desestabilizar el orden del mundo, e invertir los estamentos.

\section{El casamiento}

La descripción de los sucesos primeros que involucran al tohueyo, su aparición y el casamiento, permite que analicemos la perspectiva del narrador frente al carácter sexual del mito que reconstruye a partir de los testimonios. Como representante del mundo oficial, Sahagún debería condenar y proscribir de su discurso toda referencia a las partes sexuales del cuerpo humano, como 
de hecho, denuncia e ironiza Todorov, hacen sus traductores; sin embargo, Sahagún permite que se expresen libremente y en su sentido preciso las expresiones sexuales del relato para señalar el falo del tohueyo. En cambio, en cuanto a la imagen femenina, creemos que el conflicto entre el recato de su condición de sacerdote y la fidelidad a su labor de cronista se hace más evidente. A pesar de ello, su escritura permite que el tema tabú emerja por medio de las figuras retóricas, que inauguran una nueva realidad, acorde con el sentido de renovación del carnaval.

Cuando Sahagún hace referencia al deseo de la hija de Uémac, no tiene ningún problema en señalar que el deseo se focaliza en el miembro viril del tohueyo. Como resultado, el deseo de la mujer hace que esta se enferme de amores. Es decir, la parte del cuerpo, el miembro, es destacada y representa al todo, el cuerpo. Pero cuando se trata de señalar las partes del cuerpo femenino en su momento de excitación, creemos que el narrador opera el mismo proceso de sinécdoque, pero a la inversa: ahora es el todo que representa a la parte. La mujer y no sus órganos sexuales se inflaman por el deseo que le produce ver al tohueyo desnudo y abierto al mundo, exhibiendo carnavalescamente su masculinidad en el mercado o plaza pública.

El coito, momento de renovación por excelencia, es sugerido por Sahagún, mediante la alegoría que relaciona casa y cuerpo; alegoría que no está asusente en los mitos de las antiguas culturas y religiones. El espacio del palacio es penetrado simbólicamente por el tohueyo, cuando acepta casarse con la hija de Uémac. Considérese que esta imagen puede también representar, veladamente, la penetración carnal y la fecundación del ámbito de lo popular y grotesco en el mundo oficial, el cual había dejado de comprender los cambios históricos, que nunca están separados de la vida cotidiana.

\section{La batalla}

La historia continúa hacia el escenario de una batalla que se realiza en el lugar de nacimiento de Uitzilopuchtli, Coatépec, el cual podemos considerar ya un espacio conflictivo entre el ámbito tolteca y el de sus enemigos. El tohueyo 
ha penetrado en el palacio de Uémac y de ese modo ha conseguido extender su poder divino (recordemos que se trata de Titlacaoan disfrazado) hacia el gobierno de lo temporal o político de los hombres. Sin embargo, deberá superar un ardid tendido por su suegro, que simboliza al poder político que está siendo renovado. Los antiguos pretendientes de la hija de Uémac han reclamado, indignados, al señor la presencia del tohueyo en palacio. Sienten desprecio por el forastero incivilizado (desnudo), cuyo medio de vida se desenvuelve en el mercado, espacio popular simétrico a la plaza pública del carnaval, en la cual todos los sujetos se manifiestan en igualdad u horizontalidad, radicalmente opuestos a la verticalidad del palacio.

El tohueyo es enviado a la batalla con los más despreciables del reino, los pajes enanos y cojos, tenidos en burla por su condición física. El mecanismo carnavalesco indica que estos seres incompletos y desproporcionados en la cultura oficial remontan su condición, y son los gobernantes durante el carnaval: sus naturalezas inacabadas y la risa regeneradora que provocan hace que mientras más sea la distancia que los separa de la élite proporcionada, más pesada sea la caída del destronado hacia los bajos fondos corporales. Mientras la burla sea más ácida y más penosa la injuria en el ámbito formal; más honda, rotunda y violenta será la inversión del mundo.

Efectivamente, el tohueyo elimina él solo al ejército enemigo. Los toltecas lo reciben temerosos y alegres por la victoria; le hacen grandes fiestas, lo coronan de plumas y le colocan las armas significativas; otro tanto ocurre con los pajes. El mundo al revés se encuentra en el momento de exaltación de lo grotesco. El sexual tohueyo y los deformes pajes son conducidos como héroes, pero su victoria sobre los hombres aún no es completa. Para instaurar su ciclo temporal, Titlacaoan debe eliminar a toda aquella raza de toltecas y renovar, con estas muertes, la humanidad. Estamos frente al otro sentido deparado para el término escatología, en su acepción de fin del mundo. Nos dice Eliade que, para los primitivos, «el fin del mundo ya ha ocurrido, aunque debe reproducirse en un futuro más o menos alejado» (Eliade 1994: 61). Las causas de la escatología del mundo son los pecados humanos y la decrepitud del mundo: le prosigue la creación de una nueva humanidad. 


\section{La fiesta}

La celebración ahora es convocada por el tohueyo, que usurpa el lugar desde donde Quetzalcoatl enviaba los mensajes que recorrían todo el territorio tolteca, la sierra de Tzatzitépec. Ahora los mensajes son una invitación al desenfreno. Recordemos que hemos nombrado al tohueyo como un héroe carnavalesco, esto quiere decir, que funda su existencia en la constante desacralización del antiguo mundo; es hábil para rebajar el poder y descomponerlo desde sus elementos marginales; y se manifiesta por medio de un cuerpo grotesco y abiertamente sexual.

La decisión sobre el destino del mundo, impredecible como era toda determinación de Titlacaoan, dios alabado e injuriado a la vez por sus devotos, será determinada por el rigor de la fiesta. Los afectos a Titlacaoan conocían la caprichosa voluntad de su divinidad; solo quedaba comprobarlo en proporciones cósmicas: el mundo debe ser golpeado, para procurar su renovación; esta es la máxima de las formas carnavalescas. Titlacaoan convoca a los tulanos y los forasteros, y en medio de una frenética danza, apurada por la evidente ebriedad, mata a todos los danzantes, que caen despeñados al ritmo de un tambor sísmico.

La verdad festiva se ha abierto paso entre el engaño, y las intenciones de Titlacaoan se hacen realidad. Los poderosos que antes lo habían ofendido, ahora están sujetos a un trance que extrae lo peor de sí mismos. La solemnidad de la muerte, como en el carnaval, está ausente en la imagen de los desbarrancados: no se lamentan, no gimen, ni se angustian, simplemente bailan «sin seso», enajenados. Todos caen a las entrañas de la tierra, regresan a ella, son devorados y caen cerca del río renovador. Sus muertes no son consideradas individualmente, ya que es toda una raza la que se regenera; en ella opera la medicina del carnaval: el cuerpo vivo excreta lo muerto para seguir vivo.

\section{FIN DEL CICLO DE LOS DIOSES: LOS EMBUSTES}

Del octavo al undécimo capítulo se encuentran los llamados, por Sahagún, embustes de los nigrománticos. En partes anteriores hemos señalado 
la ambigüedad de esta denominación, más laudatoria que injuriosa. La humanidad está siendo regenerada por los dioses subversivos y cada espacio del anterior dominio de Quetzalcoatl va siendo desacralizado, subvertido y rebajado. En su segunda transformación, Titlacaoan, adopta la forma de un valiente llamado Tequioa, quien convoca a los comarcanos de Tula a la huerta de Quetzalcoatl para hacer unas obras. El lugar de la abundancia, descrito como la huerta donde el dios cultivaba sus gigantescas frutas para saciar al pueblo, ahora será regado con la sangre de los toltecas. Las actividades aprendidas de Quetzalcoatl van siendo desvirtuadas; el trabajo de cosecha que antes simbolizaba abundancia de vida, ahora otorga cruel muerte a los convocados.

El segundo embuste lo realizan, en compañía, Titlacaoan, ahora llamado Tlacauepan, y Uitzilopuchtli. El escenario regresa a la plaza pública del carnaval: el mercado. En él se representa un espectáculo: un hombre (Tlacauepan) hace danzar a un muchacho (Uitzilopuchtli) en la palma de la mano. Estamos frente a la imagen del espectáculo festivo del enano y el gigante, hiperbolizaciones que cercenan o extienden el cuerpo hacia sus confines, sin límite establecido con el mundo. No es difícil relacionar al gigante con el poder carnavalesco de los nuevos dioses desestabilizadores y al enano o muchacho danzante con el pueblo de Tula, ya sojuzgado. La recreación dramática toma visos de burla y humor. Los dioses carnavalescos están representando su propio dominio frente a los fatuos dominados, que se aglomeran y mueren, ebrios y frenéticos en medio del espectáculo.

Cuando el propio Titlacaoan los incita a apedrearlos, los dominados toltecas logran abatir a los embusteros, pero aún así el cadáver hiede y el hedor mata a los toltecas; ocurre de modo dimilar cuando intentan levantarlos con cuerdas: las cuerdas se rompen y aniquilan a los tullanos.

La ironía surge cuando los dioses mismos, omnipresentes (recordemos que esa es la característica de Titlacaoan), ordenan que se le dedique un verso de canto al cadáver. En esta parte, la mofa carnavalesca se yergue sobre la muerte, la regenera, y derrumba cualquier contenido solemne. El espectáculo inaudito atrae a los toltecas hacia una muerte festiva e inconsciente, se repite la fórmula: «los que bolvieron no sentían aquello que le havía acaecido porque estaban borrachos». 
Tula está ahora cercado; sus habitantes, diezmados; y las señales indican que han perdido el lazo entre su gobierno temporal y su gobierno cósmico. La tierra está enferma como Quetzalcoatl, la devoción decae porque su contraparte en la realidad ya no se comprueba. Los poderosos dioses desacralizadores hacen llover piedras, envían seres sobrenaturales (una vieja, una india) que, desde los lugares sagrados de la época de Quetzalcoatl, cumplen el trabajo de seguir renovando la humanidad, exterminando a los toltecas.

Los tres últimos capítulos del macrorelato se encargan de relatar la huida final de Quetzaloatl, quien se dirige finalmente a Tlapalla, donde Titlacaoan le había indicado que debía ser su retiro. En su retirada, va fundando ciudades, dejando rastros de la cultura que había fundado en Tollan; deja señales sobrenaturales con las protuberancias regeneradoras de su cuerpo: las manos y las nalgas, partes sagradas del cuerpo cósmico que simbolizan su actividad civilizadora: las manos del hacedor que ha impulsado a la humanidad, y las posaderas, marca de su permanencia en el poder. En el transcurso, los nigrománticos se encargan de interrogarlo sobre sus intenciones y se aseguran de que se aleje definitivamente. Quetzalcoatl configura la imagen del rey destronado del carnaval, rebajado y alcanzado por los elementos de renovación; va retirándose con su tristeza sombría, que poco a poco va haciéndose festiva, una vez que los dioses renovadores le convidan nuevamente el licor. Quetzalcoalt, pasa entonces de ser un sacerdote ascético, imagen de lo proporcionado y establecido, a volverse él mismo, poco antes de reintegrarse al sol (para regenerarse), un ser carnavalesco. Luego del bebedizo, adquiere la lucidez de la locura, otro elemento importante de las disparidades carnavalescas. Este Hércules, según lo nombra Sahagún, termina por perderse en los campos, edificar casas en las profundidades de la tierra y embelezarse por el juego de pelota. El rey, ya destronado, en relación horizontal con el mundo, puede ejercer ya la libertad que le era negada en su condición solemne.

\section{Conclusiones}

1. Podemos concluir que la macrohistoria y la microhistoria que, en la recopilación de Sahagún, relatan míticamente la subversión y la regeneración 
del mundo tolteca están impregnados de los aspectos universales de las formas expresivas carnavalescas: la risa y la renovación del mundo.

2. Con respecto a la pragmática del texto, podemos decir que el autor implícito de Sahagún mantiene su objetividad, pero, en ciertos momentos del relato, impone sus conocimientos culturales con miras a cubrir la expectativa de su lector modélico: el clero; sin embargo, al hacerlo traspone imágenes de la cultura popular de su época, heredera de la Edad Media - la comparación con los dioses paganos y el registro de las formas injuriosas ambivalentes- que permiten que el germen del carnaval perviva tanto en la historia que se cuenta, como en la intencionalidad del cronista. 


\section{BIBLIOGRAFÍA}

BAJTín, Mijail

1985 Estética de la creación verbal. México, D. F.: Siglo XXI.

1988 La Cultura popular en la Edad Media y en el Renacimiento. Madrid: Alianza Editorial.

1993 Problemas de la poética de Dostoievski. México, D. F.: Fondo de Cultura Económica.

Brotherston, Gordon

1997 La América indígena en su literatura: los libros del Cuarto Mundo. México, D. F.: Fondo de Cultura Económica.

De SAHAGún, fray Bernardino

1984 El méxico antiguo. Edición de José Luis Martínez. Caracas: Biblioteca Ayacucho.

2001 Historia general de las cosas de la Nueva España. Edición de Juan Carlos Temprano Madrid: Dastin.

Eliade, Mircea

1985 Lo sagrado y lo profano. Traducción de Luis Gil. Barcelona: Labor.

1994 Mito y realidad. Traducción de Luis Gil. Barcelona: Labor.

JesI, Furio

1972 Literatura y mito. Traducción de Antonio Pigrau. Barcelona: Barral Editores.

Todorov, Tzvetan

2003 La Conquista de América. La cuestión del otro. Buenos Aires: Siglo Veintiuno. 